\title{
The effect of intra-articular injection of autologous bone marrow stem cells on pain and knee function in patients with osteoarthritis
}

\author{
Domingo GARAY-MENDOZA, ${ }^{1}$ Laura VILLARREAL-MARTÍNEZ, ${ }^{2}$ iD \\ Alejandra GARZA-BEDOLLA, ${ }^{2}$ Daniela M. PÉREZ-GARZA, ${ }^{2}$ Carlos ACOSTA-OLIVO, ${ }^{1}$ \\ Felix VILCHEZ-CAVAZOS, ${ }^{1}$ Cesar DIAZ-HUTCHINSON,${ }^{1}$ David GÓMEZ-ALMAGUER, ${ }^{2}$ \\ José C. JAIME-PÉREZ ${ }^{2}$ and Consuelo MANCÍAS-GUERRA ${ }^{2}$ \\ ${ }^{1}$ Traumatology and Orthopaedics Service, Hospital Universitario "Dr. José Eleuterio González", Universidad Autónoma de Nuevo \\ León, and ${ }^{2}$ Hematology Service, Hospital Universitario "Dr. José Eleuterio González", Universidad Autónoma de Nuevo León, \\ Monterrey, México
}

\begin{abstract}
Aim: Management of osteoarthritis (OA) is basically symptomatic. Recently, stem cells (SC) have been used in the search for an optimum treatment. We decided to conduct a controlled clinical trial to determine if a single intra-articular injection of in vivo stimulated bone marrow SC could lead to an improvement in pain management and quality of life in patients with knee OA.

Method: This was a prospective, open-label, phase I/II clinical trial to assess the safety and efficacy of a single intra-articular injection of autologous stimulated bone marrow stem cells (BM-SC) in patients with knee OA. Individuals of both genders older than 30 years with confirmed diagnosis of OA who signed informed consent were included in two groups: SC group received in vivo BM stimulation with subcutaneous administration of granulocyte colony stimulating factor (G-CSF). SC were obtained by BM aspiration and administered in a single intra-articular injection. The control group received exclusively oral acetaminophen. Visual analogue scale and Western Ontario and McMaster Universities Osteoarthritis Index scores were performed at 1 week, 1 month and 6 months in both groups. This trial was registered in ClinialTrials.gov NCT01485198.

Results: A total of 61 patients were included. Socio-demographic characteristics, OA grades and initial scores were similar in both groups. The BM-SC group showed significant improvement in knee pain and quality of life during the 6-month follow-up.

Conclusion: The study demonstrates feasibility and supports efficacy of a completely ambulatory procedure in treatment of knee OA.
\end{abstract}

Key words: bone marrow, knee osteoarthritis, stem cells.

Correspondence: Dr Laura Villarreal Martinez, Hematology Service, Hospital Universitario "Dr. José Eleuterio González", Ave. Madero y Gonzalitos s/n, Mitras Centro, Monterrey, N. L., 64460, México. Email: dr_lauravillarreal@hotmail.com

\section{INTRODUCTION}

Osteoarthritis (OA) is the most common musculoskeletal disease and occurs in around $15 \%$ of the world population over 60 years of age. It is a painful and 
disabling degenerative disease that can affect any joint, with the knee being the most common site. ${ }^{1}$ The risk of developing $\mathrm{OA}$ increases with each decade after 45 years of age. ${ }^{2}$ In OA numerous biological molecules produce cartilage destruction. Chondrocytes produce mediators of inflammation such as cytokines, chemokines, and proteolytic enzymes that induce further damage. The progression of $\mathrm{OA}$ can lead to total knee replacement, which carries important costs and possible serious complications.

Currently OA treatment is mostly pharmacologic and symptomatic, with optimum treatment requiring effective analgesia, improving joint function, stopping progression of chondral degeneration, and if possible, regenerating damaged cartilage. There is no treatment available to stop progression or revert damage already present. Acetaminophen is the drug of choice for pain management due to its safety at recommended doses. ${ }^{1,3}$ It has been used for pain relief in OA for about a century; however, its efficacy has been recently challenged in a systematic review. ${ }^{4}$ Thus, an effective, safe and lowcost treatment for OA is necessary. Ideal therapy should provide pain relief, stop progression, modify cartilage structure and revert damage. ${ }^{5}$ New treatment options include tissue engineering for tissue regeneration, which includes harvesting and transplant methods. ${ }^{6,7}$ Tissue auto-transplant is a well-established strategy for treatment of damaged or lost tissue after a trauma, oncological resection, congenital deformities or progressing degenerative disease. ${ }^{8}$

In this field stem cells (SC) have been studied. There are different sources of adult SC; the most common is bone marrow (BM), where they are harvested and administrated locally or systemically. In cell therapy, BM offers some advantages over other sites of collection because it offers a higher concentration of SC in less volume, it is of easy access, there is no need for a central venous catheter, and excludes performing more troublesome procedures like apheresis. ${ }^{9}$ These cells have the potential of producing therapeutic effects based on their capacity to regenerate joint chondral lesions and relieve symptoms, particularly those due to the secretion of diverse factors and cell-to-cell interaction. ${ }^{10}$ Also, there are additional advantages in centers with budget and bed availability limitations, as the procedure can be a totally outpatient intervention and only a visit to the hospital is needed for collecting, processing and injecting SC.

There are few studies reporting outcomes after stem cell therapy in knee OA. ${ }^{11}$ Centeno et al. and Wakitani et al. ${ }^{12,13}$ reported the first OA cases treated with BM-SC injection with promising results. Importantly, there are no previous reports of in vivo BM stimulation followed by a single SC intra-articular injection without surgical intervention. We conducted a prospective trial to determine if intra-articular injection of in vivo stimulated $\mathrm{BM}-\mathrm{SC}$ is a safe procedure and could lead to improvement in pain management and quality of life in patients with knee OA.

\section{PATIENTS AND METHODS}

\section{Study design}

This was a prospective, open-label, phase I/II clinical trial to assess the safety, tolerability and efficacy of a single intra-articular injection of autologous bone marrow stem cells (BM-SC) in patients with knee OA.

Patients were recruited from the orthopedic surgery clinic and the intervention procedure was carried out at the hematology service, both from the University Hospital "Dr. José Eleuterio González", Mexico.

Patients with the following characteristics were included: individuals of both genders aged over 30 years and with a confirmed diagnosis of knee OA made by clinical and radiological evaluation, with unilateral affection, and at least 6 months of progression. They were classified as OA grades II and III according to the Kellgren and Lawrence radiological classification system. All participants provided informed consent and were divided into two homogenous groups, in which socio-demographic characteristics, OA grades, and initial visual analogue scale (VAS), which evaluated pain on a numerical scale from 0 to 10 , where 0 signified no pain and 10 signified the worst pain experienced by the patient, and the Western Ontario and McMaster Universities Arthritis Index (WOMAC) scores were equal.

Patients with systemic arthritis, a knee infection or surgery in the last 6 months, an intra-articular injection in the past 3 months, or neurodegenerative, autoimmune, malignant or traumatic lesions (joint fracture, meniscal or ligament injury) were excluded. Hypothesis testing of the difference between two population means was used to determine sample size.

A knee X-ray in two positions, comparative anteriorposterior (AP) and lateral in standing position, were obtained from each participant at the beginning of the study. VAS and WOMAC scales were made at baseline, 1 week, 1 month, and after 6 months of intervention. The Review Board and Ethics Committee of our institution approved the study. This trial was registered in ClinialTrials.gov NCT01485198. 


\section{Stem cell group}

\section{Initial evaluation}

Before starting SC stimulation, a complete medical evaluation was performed, including medical history, physical examination, complete blood count and biochemical profile. Infectious diseases such as human immunodeficiency virus, hepatitis $\mathrm{B}$ and $\mathrm{C}$ were ruled out. Subsequently, VAS and WOMAC data were collected.

\section{Stimulation and harvesting of SC}

After overall assessment, autologous SC stimulation was started with the subcutaneous administration of $600 \mu \mathrm{g}$ per day of granulocyte colony stimulating factor (G-CSF) (Biofilgran, Landsteiner Scientific, Mexico City, Mexico) for 3 consecutive days on an outpatient basis, before the procedure. A complete blood count (CBC) was performed to determine the increase in cell concentration in peripheral blood on the day of BM harvesting (white blood cell count: pre-G-CSF $8.22 \times 10^{3} \mu \mathrm{L}$, post-G-CSF: $36.60 \times 10^{3} \mu \mathrm{L}$ ). Bone marrow aspiration was performed using local anesthesia with xylocaine at $2 \%$ and with the patient under sedation with intravenous midazolam at $0.1 \mathrm{mg} / \mathrm{kg}$. Patients were placed in the prone position, and after aseptic maneuvers, Jamshidi needles (Carefusion Corporation, Chicago, IL, USA) were inserted in both posterior iliac crests to aspirate a $\mathrm{BM}$ volume of $75 \mathrm{~mL}$ from each iliac crest. The harvested BM aspirate was collected in three sterile 50$\mathrm{mL}$ Corning tubes (Corning Incorporated, Corning, NY, USA) with a previously added anticoagulant solution composed of a $1: 100$ dilution of 1000 units of heparin and citrate dextrose.

\section{Stem cell isolation}

BM-derived SC isolation was set to obtain a final volume of $10 \mathrm{~mL}$ for intra-articular administration. After harvesting, BM contained in the Corning tubes was filtered in a laminar flow cabinet using a $180-\mu$ blood filter. A sample of $0.5 \mathrm{~mL}$ was taken to perform BM-CBC.

$\mathrm{BM}$ was centrifuged at $2600 \times g$ for $15 \mathrm{~min}$ at $6^{\circ} \mathrm{C}$ and returned to the flow cabinet. Plasma was removed with a 16-gauge needle $2 \mathrm{~mm}$ above the buffy coat and discarded. The buffy coat was obtained manually with the use of a $10-\mathrm{mL}$ syringe, in approximately $3.3 \mathrm{~mL}$ of volume for each of the BM harvest tubes. This process was performed while attempting to obtain a rich-cell buffy coat with as few red blood cells as possible.

A 0.5-mL sample of the collected buffy coat was used to perform a CBC, bacterial cultures, and flow cytometry for $\mathrm{CD} 45^{+}, \mathrm{CD} 34^{+}$and viability determination. Flow cytometry enumeration of CD $34^{+}, \mathrm{CD} 45^{+}$cells and viability assessment were made with the single-platform ISHAGE (International Society of Hematotherapy and Graft Engineering) technique in a FACSCalibur cytometer with anti-CD34, anti-CD45 antibodies and 7-aminoactinomycin $\mathrm{D}$, respectively. Cells were not selected or separated by apheresis nor cultured for induction or expansion.

\section{Intra-articular cell administration}

Intra-articular stem cell (IA-SC) injection was made on the same day, 90 min after the bone marrow harvesting. The patient was placed in a supine position with the affected knee flexed at $70^{\circ}$. After surgical cleaning and local anesthesia with $3 \mathrm{~mL}$ of $1 \%$ xylocaine at the puncture site, a $10 \mathrm{~mL}$ concentrate of BM SCs was injected with an $18 \mathrm{G} \times 1$ " needle infra-patellar immediately lateral to the patellar tendon into the lateral compartment intra-articular space of the affected knee. All patients were injected by the same orthopedic surgeon. The intra-articular injection was made on an outpatient basis.

\section{Control group}

Patients enrolled in the control group underwent treatment with oral acetaminophen $500 \mathrm{mg}$ every $8 \mathrm{~h}$ for 6 months. As in the SC group, patients were evaluated with VAS and WOMAC scales at baseline, 1 week, 1 month and 6 months. Between these periods of time no other intervention was made in this group.

\section{Follow-up and further assessment}

Follow-up of patients from both groups was carried out on an outpatient basis. VAS and WOMAC were performed by the same team at baseline, 1 week, 1 month and 6 months.

\section{Statistical analysis}

For comparisons between groups Student's t-test was used for quantitative variables and the Mann-Whitney $U$-test for non-parametric variables. Absolute frequencies and percentiles were calculated and compared using either the Chi-squared test or Fisher' exact test. Statistical analysis was made with SPSS version 20 (IBM, Armonk, NY, USA).

\section{RESULTS}

A total of 61 patients were recruited: 30 in Group 1 (SC group) and 31 in Group 2 (acetaminophen group). Ten patients were lost during follow up, four and six, respectively (Fig. 1). 


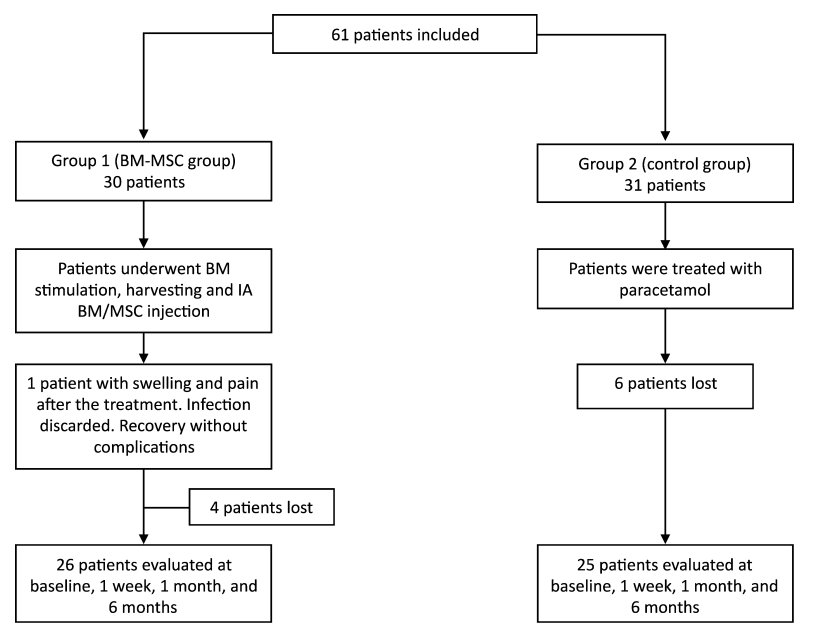

Figure 1 Patient distribution.

Table 1 Comparison of demographic characteristics between groups

\begin{tabular}{lccl}
\hline Characteristic & Group 1 & Group 2 & $P$-value \\
\hline$N$ & 30 & 31 & - \\
Gender & & & \\
Male & $7(23 \%)$ & $9(29 \%)$ & - \\
Female & $23(77 \%)$ & $22(71 \%)$ & \\
Weight, kg & $78.23 \pm 13.00$ & $80.41 \pm 17.52$ & 0.58 \\
Height, $\mathrm{m}$ & $1.63 \pm 0.07$ & $1.59 \pm 0.86$ & 0.10 \\
Age, years & $55.67 \pm 12.02$ & $59.32 \pm 10.85$ & 0.21 \\
BMI, kg/m ${ }^{2}$ & $29.48 \pm 5.22$ & $31.61 \pm 7.38$ & 0.20 \\
\hline
\end{tabular}

BMI, body mass index.

Socio-demographic characteristics such as gender, age, weight, height and body mass index (BMI) were similar in both groups (Table 1).

According to the OA Kellgren-Lawrence classification there were no statistically significant differences between the two groups.

The mean number of BM total nucleated cells was $302.02 \times 10^{7}\left(155 \times 10^{7}-469.23 \times 10^{7}\right)$, and the mean number of BM mononuclear cells was $67.33 \times 10^{7}\left(31.52 \times 10^{7}-114.02 \times 10^{7}\right)$. The mean number of $\mathrm{CD}^{2} 4^{+}$cells injected was $20.56 \times 10^{6}$ $\left(5.2 \times 10^{6}-43.36 \times 10^{6}\right)$.

\section{Scores}

Initial scores for VAS and WOMAC were similar in both groups: VAS for Group $1 \quad(x \pm$ SD): $5.27 \pm 2.196$ and for Group $2(x \pm$ SD $): 4.32 \pm 2.35$
Table 2 Comparison of VAS and WOMAC evaluations between groups

\begin{tabular}{|c|c|c|c|}
\hline Variable & $\begin{array}{l}\text { Group } 1 \\
(x \pm \text { SD } \\
N=26)\end{array}$ & $\begin{array}{l}\text { Group } 2 \\
(x \pm \mathrm{SD} \\
N=25)\end{array}$ & $P$-value \\
\hline VAS 1 week & $2.31 \pm 2.24$ & $4.40 \pm 2.44$ & 0.003 \\
\hline VAS 1 month & $1.62 \pm 2.04$ & $4.24 \pm 2.72$ & $<0.0001$ \\
\hline VAS 6 months & $0.92 \pm 1.29$ & $4.64 \pm 2.43$ & $<0.0001$ \\
\hline $\begin{array}{l}\text { WOMAC } \\
1 \text { week }\end{array}$ & $80.72 \pm 20.41$ & $71.62 \pm 14.62$ & 0.07 \\
\hline Pain & $82.59 \pm 15.15$ & $71.07 \pm 17.12$ & 0.011 \\
\hline Stiffness & $85.26 \pm 18.95$ & $65.59 \pm 22.40$ & 0.001 \\
\hline $\begin{array}{l}\text { Physical } \\
\text { function }\end{array}$ & $80.50 \pm 19.65$ & $74.52 \pm 15.95$ & 0.218 \\
\hline $\begin{array}{l}\text { WOMAC } \\
1 \text { month }\end{array}$ & $88.58 \pm 17.12$ & $69.92 \pm 14.87$ & $<0.0001$ \\
\hline Pain & $88.70 \pm 17.24$ & $70.35 \pm 17.37$ & $<0.001$ \\
\hline Stiffness & $88.88 \pm 20.31$ & $67.59 \pm 23.57$ & 0.001 \\
\hline $\begin{array}{l}\text { Physical } \\
\text { function }\end{array}$ & $87.62 \pm 17.61$ & $73.34 \pm 16.22$ & 0.003 \\
\hline $\begin{array}{l}\text { WOMAC } \\
6 \text { months }\end{array}$ & $91.73 \pm 9.45$ & $72.96 \pm 15.04$ & $<0.0001$ \\
\hline Pain & $92.30 \pm 9.40$ & $68.80 \pm 18.44$ & $<0.001$ \\
\hline Stiffness & $92.30 \pm 11.22$ & $70.00 \pm 21.65$ & $<0.001$ \\
\hline $\begin{array}{l}\text { Physical } \\
\text { function }\end{array}$ & $91.48 \pm 9.79$ & $72.29 \pm 14.84$ & $<0.001$ \\
\hline
\end{tabular}

Scores are based on a 0-100 point scale (100 points indicates the best score). Each subscale of WOMAC is based on a $0-100$ point scale. VAS, visual analogye scale; WOMAC, Western Ontario and McMaster Universities Osteoarthritis Index.

$(P=0.10)$. WOMAC for Group $1 \quad(x \pm \mathrm{SD})$ : $62.61 \pm 18.55$ compared to Group $2(x \pm \mathrm{SD})$ $69.93 \pm 17.89 \quad(P=0.12)$. Further evaluations at 1 week, 1 month and 6 months showed a statistically significant improvement in VAS scale, and 1 month and 6 months in WOMAC for Group 1 (Table 2, Fig. 2). Data between genders comparing initial scores with follow up are presented in Table 3 . The mean number of $\mathrm{CD}^{2} 4^{+}$cells injected was $20.56 \times 10^{6}$ (range: $5.2 \times 10^{6}-43.36 \times 10^{6}$ ).

\section{Adverse events}

A patient from Group 1 presented swelling and pain in the knee the day after the SC-IA injection. Infection was ruled out and the patient recovered without further complications. Bone pain was referred by 12 patients during the stimulation with G-CSF. Some patients referred slight pain and stiffness during the first $48 \mathrm{~h}$ after the injection. No other clinical complications were noticed. 


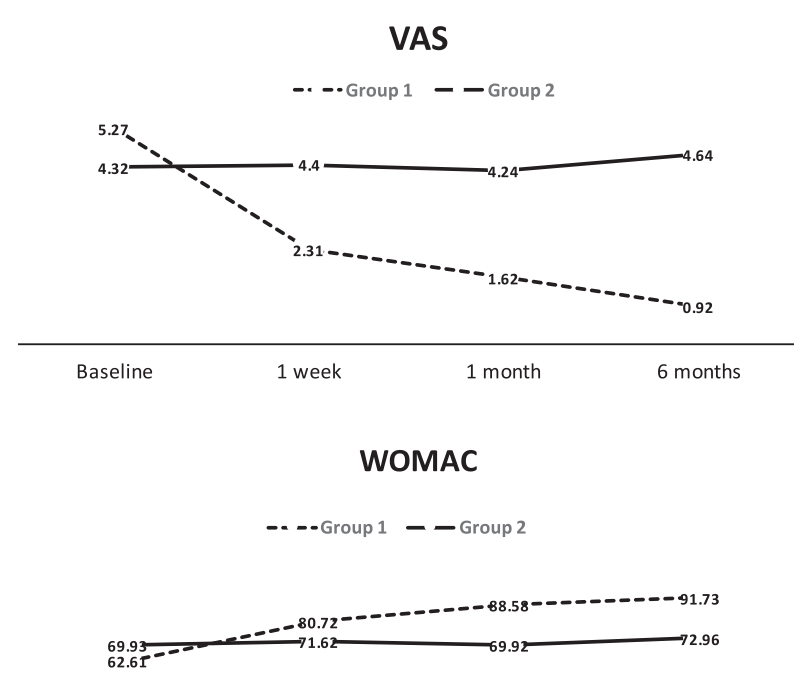

Baseline

1 week

1 month

6 months

Figure 2 Graph showing visual analogue (VAS) and Western Ontario and McMaster Universities Osteoarthritis Index (WOMAC) scores: Group 1 versus Group 2.

\section{DISCUSSION}

As recently reviewed, ${ }^{14}$ current research focuses on the development of new OA drugs, including recombinant human fibroblast growth factor-18, tanezumab monoclonal antibody against $\beta$-nerve growth factor ${ }^{15}$ pursuing greater effectiveness and lower rates of adverse events. Regenerative approaches, including autologous chondrocyte implantation (ACI), cell-free scaffolds and induced pluripotent stem cells, among others, are plausible alternatives to enhance cartilage repair, and restore healthy tissue. ${ }^{14}$ Despite these advances, much remains to be done in order to provide effective treatment options for OA. In our study, the beneficial effect of BM-SC was evaluated in knee OA. As mentioned before, we decided to use autologous $\mathrm{BM}$ because it has a higher concentration of SC in less volume, and has an easier access, also this protocol is financially sustainable, is carried out totally in an outpatient setting and we have experience performing it for hematologic and non-hematologic diseases. ${ }^{9,16}$ Systemic mobilization of $\mathrm{SC}$ and other BM precursors $\left(\mathrm{CD} 34^{+}\right)$using growth factors represents minimum manipulation and consequently a reduction in the risk of introducing viruses and prions. ${ }^{17,18}$ Therefore, we used SC from BM stimulated in vivo. It is important to consider that BM hematopoietic stem cells, mesenchymal progenitors and immune cells increase significantly after G-CSF stimulation in vivo. ${ }^{19}$ Furthermore, in the present study G-CSF was used for stimulation in vivo because there is an age-dependent factor which has influence in the decrease in the number of progenitor cells in BM in elderly patients ${ }^{20}$ and G-CSF increases the number of hematopoietic stem cells in BM. ${ }^{21,22}$ The safe use of GCSF in healthy donors has been studied, with minor side effects such as headache, bone pain, weakness and nausea, which are generally transient and well tolerated. $^{23}$

Regarding the control group we used paracetamol since it was considered as the first line treatment, relieving pain and improving physical functioning with low long-term toxicity. ${ }^{3}$

To our knowledge this is the first clinical controlled trial with autologous BM-SC stimulated in vivo with a single intra-articular injection for the treatment of knee OA. Our study differs from other research developed in

Table 3 Differences between genders comparing initial scores with scores at 7, 30 and 180 days

\begin{tabular}{|c|c|c|c|c|c|c|c|c|}
\hline & \multicolumn{4}{|c|}{ Group 1} & \multicolumn{4}{|c|}{ Group 2} \\
\hline & \multicolumn{2}{|c|}{ Male $N=7$} & \multicolumn{2}{|c|}{ Female $N=23$} & \multicolumn{2}{|c|}{ Male $N=9$} & \multicolumn{2}{|c|}{ Female $N=22$} \\
\hline & $(x \pm \mathrm{DS})$ & $P$ & $(x \pm \mathrm{DS})$ & $P$ & $(x \pm \mathrm{DS})$ & $P$ & $(x \pm \mathrm{DS})$ & $P$ \\
\hline WOMAC_0 & $75.05 \pm 15.12$ & & $59.38 \pm 18.67$ & & $75.62 \pm 18.26$ & & $67.62 \pm 17.61$ & \\
\hline WOMAC_7 & $82.42 \pm 14.88$ & 0.135 & $80.70 \pm 20.88$ & $<0.001$ & $71.20 \pm 13.73$ & 0.728 & $72.45 \pm 15.10$ & 0.082 \\
\hline WOMAC_30 & $85.42 \pm 20.62$ & 0.024 & $88.65 \pm 16.61$ & $<0.001$ & $72.95 \pm 17.70$ & 0.988 & $69.52 \pm 13.81$ & 0.883 \\
\hline WOMAC_180 & $88.24 \pm 11.66$ & 0.007 & $92.70 \pm 8.87$ & $<0.001$ & $75.38 \pm 13.23$ & 0.68 & $71.81 \pm 16.07$ & 0.252 \\
\hline VAS_0 & $6 \pm 1.78$ & & $5.08 \pm 2.28$ & & $4.44 \pm 1.94$ & & $4.27 \pm 2.49$ & \\
\hline VAS_7 & $3 \pm 1.41$ & 0.018 & $2.09 \pm 1.75$ & $<0.001$ & $5.25 \pm 2.81$ & 0.685 & $4.15 \pm 2.25$ & 0.929 \\
\hline VAS_30 & $3 \pm 4.76$ & 0.182 & $1.39 \pm 1.11$ & $<0.001$ & $5.00 \pm 3.024$ & 0.857 & $4.00 \pm 2.66$ & 0.884 \\
\hline VAS_180 & $88.24 \pm 11.66$ & 0.007 & $92.70 \pm 8.87$ & $<0.001$ & $75.38 \pm 13.23$ & 0.68 & $71.81 \pm 16.07$ & 0.252 \\
\hline
\end{tabular}

WOMAC, Western Ontario and McMaster Universities Osteoarthritis Index; VAS 
recent years regarding the potential of SC in cartilage regeneration using different techniques and SC sources. Previous studies in animal models have demonstrated the potential benefit of stem cells in cartilage degeneration. ${ }^{24-29}$ In humans, other studies have been performed using stem cells from different collection sites such as adipose tissue $e^{30-33}$ or peripheral blood through apheresis. ${ }^{34,35}$ Some studies include case series and clinical trials with BM mesenchymal cells; some of them administered the cells by means of surgical intervention $^{13,36-38}$ and others with intra-articular injection. ${ }^{12,39-42}$

We evaluated our results by means of VAS and WOMAC scales, since these have been used in many other knee OA studies, ${ }^{40}$ in order to determine knee function and pain, and found that there was an improvement from the first week in the BM-SC group. In this setting it is possible that SCs have an antiinflammatory effect, which could explain the short-term clinical improvement. The immunoregulatory effects strongly inhibit T-cell recognition and expansion by inhibiting tumor necrosis factor- $\alpha$ and interferon- $\gamma$ production and thus, increasing interleukin-10 levels. ${ }^{43}$ This benefit continued with a rising trend during subsequent evaluations. The BM-SC group obtained a significant improvement in knee pain and quality of life since first evaluation until the last one at 6 months.

Our study has important limitations, such as a short follow-up and the absence of a radiological study or histological examination to demonstrate an increase in cartilage volume, and also we did not performed a detailed evaluation of the contralateral knee. However, our main goal, to assess safety, tolerability and efficacy of autologous SC intra-articular injection for pain control in knee OA was successfully accomplished. The advantages of the methodology employed are easy access to SCs, no need for hospitalization or in vitro cell expansion, due to in vivo stimulation which importantly decrease the disadvantages of manipulation and high cost.

In conclusion, the present study demonstrates the feasibility of a completely ambulatory procedure with a low risk and low possibility of complication. This suggests that the use of autologous BM-SC could be a promising potential therapy for knee OA, and interesting area of future research.

\section{DISCLOSURE OF INTERESTS}

The authors have no commercial, proprietary or financial interest in the products or companies described in this article.

\section{REFERENCES}

1 Wieland HA, Michaelis M, Kirschbaum BJ, Rudolphi K (2005) Osteoarthritis - an untreatable disease? Nat Rev Drug Discov 4 (4), 331-44.

2 Vincent HK (2013) The pathophysiology of osteoarthritis: a mechanical perspective on the knee joint. PMR 4 (5), 111.

3 Jawad ASM (2005) Analgesics and osteoarthritis: are treatment guidelines reflected in clinical practice? Am J Ther [Internet] 12 (1), 98-103. Available from: http://www.ncb i.nlm.nih.gov/pubmed/15662297

4 Ennis ZN, Dideriksen D, Vaegter HB, Handberg G, Pottegård A (2016) Acetaminophen for chronic pain: a systematic review on efficacy. Basic Clin Pharmacol Toxicol [Internet] 118 (3), 184-9. Available from: http://www.ncb i.nlm.nih.gov/pubmed/26572078

5 Richette P, Bardin T (2004) Structure-modifying agents for osteoarthritis: an update. Joint Bone Spine 71 (1), 18-23.

6 Sponer P, Kučera T, Diaz-Garcia D, Filip S (2014) The role of mesenchymal stem cells in bone repair and regeneration. Eur J Orthop Surg Traumatol 24 (3), 257-62.

7 Fong E, Chan C, Goodman S (2011) Stem cell homing in musculoskeletal injury. Biomaterials [Internet] 32 (2), 395-409. Available from: http://www.sciencedirect.c om/science/article/pii/S0142961210011397

8 Swearingen $\mathrm{B}$, Ravindra $\mathrm{K}, \mathrm{Xu} \mathrm{H}, \mathrm{Wu} \mathrm{S}$, Warren C, Ildstad ST (2008) The science of composite tissue allotransplantation. Transplantation 86 (5), 627-35.

9 Mancías-Guerra C, Marroquín-Escamilla AR, GonzalezLlano O et al. (2014) Safety and tolerability of intrathecal delivery of autologous bone marrow nucleated cells in children with cerebral palsy: an open-label phase I trial. Cytotherapy 16 (6), 810-20.

10 Pintan GF, De Oliveira AS, Lenza M, Antonioli E, Ferretti M (2014) Update on biological therapies for knee injuries: osteoarthritis. Curr Rev Musculoskelet Med 7 (3), 263-9.

11 Anderson JA, Little D, Toth AP et al. (2014) Stem cell therapies for knee cartilage repair: the current status of preclinical and clinical studies. Am J Sport Med 42 (9), 2253-61.

12 Centeno CJ, Busse D, Kisiday J, Keohan C, Freeman M, Karli D (2008) Regeneration of meniscus cartilage in a knee treated with percutaneously implanted autologous mesenchymal stem cells. Med Hypotheses [Internet] 71 (6), 900-8. Available from: https://doi.org/10.1016/j.mehy. 2008.06.042

13 Wakitani S, Nawata $M$, Tensho $K$, Okabe T, Machida $H$, Ohgushi H (2007) Repair of articular cartilage defects in the patello-femoral joint with autologous bone marrow mesenchymal cell transplantation: three case reports involving nine defects in five knees. J Tissue Eng Regen Med 1, 74-9.

14 Burke J, Hunter M, Kolhe R, Isales C, Hamrick M, Fulzele S (2016) Therapeutic potential of mesenchymal stem cell based therapy for osteoarthritis. Clin Transl Med $5(1), 27$. 
15 Lane NE, Schnitzer TJ, Birbara CA et al. (2010) Tanezumab for the treatment of pain from osteoarthritis of the knee. N Engl J Med 363 (16), 1521-31.

16 Jaime-Perez JC, Heredia-Salazar AC, Cantu-Rodriguez OG et al. (2015) Cost structure and clinical outcome of a stem cell transplantation program in a developing country: the experience in northeast Mexico. Oncologist 20 (4), 386-92.

17 Marmotti A, De Girolamo L, Bonasia DE et al. (2014) Bone marrow derived stem cells in joint and bone diseases: a concise review. Int Orthop 38 (9), 1787-801.

18 Van Der Kraan PM (2013) Stem cell therapy in osteoarthritis: a step too far? BioDrugs 27 (3), 175-80.

19 De Felice L, Agostini F, Suriano C et al. (2016) Hematopoietic, mesenchymal, and immune cells are more enhanced in bone marrow than in peripheral blood from granulocyte colony-stimulating factor primed healthy donors - clinicalkey. Biol Blood Marrow Transplant [Internet] 22 (10), 1758-64. Available from: https://0-www.c linicalkey.com.innopac.lsuhsc.edu/\#!/content/playConte nt/1-s2.0-S1083879116301902?returnurl=null\&referrer= null

20 Muschler GF, Nitto H, Boehm CA, Easley KA (2001) Ageand gender-related changes in the cellularity of human bone marrow and the prevalence of osteoblastic progenitors. J Orthop Res 19 (1), 117-25.

21 Brouard N, Driessen R, Short B, Simmons PJ (2010) GCSF increases mesenchymal precursor cell numbers in the bone marrow via an indirect mechanism involving osteoclast-mediated bone resorption. Stem Cell Res [Internet] 5 (1), 65-75. Available from: https://doi.org/10.1016/j.scr. 2010.04.002

22 Haynesworth SE, Stanton L, Caplan AI, Al LET (1997) Human bone marrow-derived mesenchymal (stromal) peripheral blood progenitor cell collections. J Hematother 6, 447-56.

23 Chen S-H, Wang T, Yang K (2013) Hematopoietic stem cell donation. Int J Hematol [Internet] 97 (4), 446-55. Available from: http://www.ncbi.nlm.nih.gov/pubmed/ 23420184\%5Cnhttp://link.springer.com/article/10.1007/ s12185-013-1298-8

24 Kehoe O, Cartwright A, Askari A, El Haj AJ, Middleton J (2014) Intra-articular injection of mesenchymal stem cells leads to reduced inflammation and cartilage damage in murine antigen-induced arthritis. J Transl Med [Internet] 12 (1), 157. Available from: http://www.scopus.com/inwa rd/record.url?eid=2-s2.0-84902276992\&partnerID= tZOtx3y1

25 Sato M, Uchida K, Nakajima H et al. (2012) Direct transplantation of mesenchymal stem cells into the knee joints of Hartley strain guinea pigs with spontaneous osteoarthritis. Arthritis Res Ther [Internet] 14 (1), R31. Available from: http://www.pubmedcentral.nih.gov/articlerender.fcgi?artid= 3392826\&tool=pmcentrez\&rendertype $=$ abstract

26 Saw KY, Hussin P, Loke SC et al. (2009) Articular cartilage regeneration with autologous marrow aspirate and hyaluronic acid: an experimental study in a goat model. Arthroscopy [Internet] 25 (12), 1391-400. Available from: https://doi.org/10.1016/j.arthro.2009.07.011

27 Singh A, Goel SC, Gupta KK et al. (2014) The role of stem cells in osteoarthritis: an experimental study in rabbits. Bone Joint Res 3 (2), 32-7.

28 Song F, Tang J, Geng R et al. (2014) Comparison of the efficacy of bone marrow mononuclear cells and bone mesenchymal stem cells in the treatment of osteoarthritis in a sheep model. Int J Clin Exp Pathol 7 (4), 1415-26.

29 Ude CC, Sulaiman SB, Min-Hwei N et al. (2014) Cartilage regeneration by chondrogenic induced adult stem cells in osteoarthritic sheep model. PLoS ONE 9 (6).

30 Chua KH, Zaman Wan Safwani WK, Hamid AA, Shuhup SK, Mohd Haflah NH, Mohd Yahaya NH (2014) Retropatellar fat pad-derived stem cells from older osteoarthritic patients have lesser differentiation capacity and expression of stemness genes. Cytotherapy [Internet] 16 (5), 599-611. Available from: https://doi.org/10.1016/ j.jcyt.2013.08.013

31 Koh YG, Choi YJ (2012) Infrapatellar fat pad-derived mesenchymal stem cell therapy for knee osteoarthritis. Knee [Internet] 19 (6), 902-7. Available from: https:/doi.org/ 10.1016/j.knee.2012.04.001

32 Koh YG, Choi YJ, Kwon SK, Kim YS, Yeo JE (2015) Clinical results and second-look arthroscopic findings after treatment with adipose-derived stem cells for knee osteoarthritis. Knee Surg Sports Traumatol Arthrosc 23 (5), 1308-16.

33 Koh YG, Jo SB, Kwon OR et al. (2013) Mesenchymal stem cell injections improve symptoms of knee osteoarthritis. Arthroscopy [Internet] 29 (4), 748-55. Available from: https://doi.org/10.1016/j.arthro.2012.11.017

34 Saw K-Y, Anz A, Siew-Yoke Jee C et al. (2013) Articular cartilage regeneration with autologous peripheral blood stem cells versus hyaluronic acid: a randomized controlled trial. Arthroscopy [Internet] 29 (4), 684-94. Available from: https://doi.org/10.1016/j.arthro.2012.12.008\%5cnpape rs2://publication/doi/10.1016/j.arthro.2012.12.008\%5cn www.ncbi.nlm.nih.gov/pubmed/23380230

35 Turajane T, Chaweewannakorn U, Larbpaiboonpong V et al. (2013) Combination of intra-articular autologous activated peripheral blood stem cells with growth factor addition/preservation and hyaluronic acid in conjunction with arthroscopic microdrilling mesenchymal cell stimulation Improves quality of life and regenera. J Med Assoc Thai 96 (5), 580-8.

36 Buda R, Vannini F, Cavallo M et al. (2013) One-step arthroscopic technique for the treatment of osteochondral lesions of the knee with bone-marrow-derived cells: three years results. Musculoskelet Surg 97 (2), 145-51.

37 Vangsness T, Farr J, Boyd J, Dellaero DT, Mills CR, LerouxWilliams M (2014) Adult human mesenchymal stem cells delivered via intra-articular injection to the knee following partial medial meniscectomy. J Bone Joint Surg Am 96, 90-8. 
38 Xia P, Wang X, Lin Q, Li X (2015) Efficacy of mesenchymal stem cells injection for the management of knee osteoarthritis : a systematic review and meta-analysis. Int Orthop 39(12), 2363-72.

39 Davatchi F, Abdollahi BS, Mohyeddin M, Shahram F et al. (2011) Mesenchymal stem cell therapy for knee osteoarthritis. Preliminary report of four patients. Int $J$ Rheum Dis [Internet] 14 (2), 211-15. Available from: http://www.ncbi.nlm.nih.gov/pubmed/21518322

40 Hauser RA, Orlofsky A (2013) Regenerative injection therapy with whole bone marrow aspirate for degenerative joint disease: a case series. Clin Med Insights Arthritis Musculoskelet Disord 6, 65-72.
41 Orozco L, Munar A, Soler R et al. (2014) Treatment of knee osteoarthritis with autologous mesenchymal stem cells. Transplantation 97 (11), e66-8.

42 Orozco L, Munar A, Soler R, Alberca M, Francesc S, Huguet M (2014) Treatment of knee osteoarthritis with autologous mesenchymal stem cells: two-year follow-up results. Transplantation [Internet] 97 (11), e66-7. Available from: http://content.wkhealth.com/linkback/openurl?sid= WKPTLP:landingpage\&an=00007890-201406150-00021

43 Caplan AI (2007) Adult mesenchymal stem cells for tissue engineering versus regenerative medicine. J Cell Physiol 213, 341-7. 